\title{
Librarians and Library Educators in the 1980s: Shared Interests, Cooperative Ventures
}

\section{Marianne Cooper and Shoshana Kaufmann}

\begin{abstract}
A project was undertaken to examine the extent of shared interests and cooperative endeavors between library schools and their host academic libraries and to determine the state of relations between the two units on academic campuses. The role of librarians in library/information science education, the involvement of library school faculty in the libraries, and the extent and effectiveness of various channels of communication between them were investigated. Data were collected by interviewing administrative personnel in five metropolitan New York-area institutions and by sending questionnaires to deans and directors of fifty-five institutions throughout the United States and Canada that had ALA-accredited library schools.
\end{abstract}

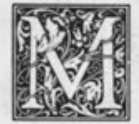

uch has been said about the need for communication and cooperation between educators and practitioners in many professions, including librarianship. Unfortunately, limited interaction, with a degree of tension, has been the hallmark of the relationship in librarianship for decades.

Library science professors and library professionals belong to two separate organizational units with different missions and needs in academic institutions. While obviously related, they are often perceived as one by the academic community, further heightening the tension between them. The chasm between the two units has deepened in recent years be- cause of greatly increased demands. Both librarians and library school faculty are forced to compete with their colleagues in other departments in the "publish or perish" syndrome in many institutions. Both units have been affected by the deteriorating economics of academe and rapid changes in information technologies. Also, administrators are increasingly taking a hard look at professional schools and reevaluating their place and mission in the university. This has led to changes in organizational structures and closings of library schools in recent years and has forced some administrators of the two units to reexamine their relationships.

An extensive search of the literature (see Bibliography) has revealed that while

Marianne Cooper is an Assistant Professor at the Graduate School of Library and Information Studies and Shoshana Kaufmann is Professor and Associate Director of the Benjamin Rosenthal Library at Queens College, City University of New York, Flushing, New York, 11367. The study upon which this paper is based was supported by a Council on Library Resources Cooperative Faculty/Librarian Grant. Their support is very much appreciated. The authors are also pleased to acknowledge the individuals interviewed and thank them for their efforts and for sharing their viewpoints frankly and candidly: their contributions to this paper were indeed substantial. Additionally, the authors are grateful to those who responded to their request for information by completing and returning the questionnaire. That information provided the authors with a broad perspective from which to draw conclusions. 
some specific aspects of the relationship between library practitioners and educators have been examined, the totality of needs and relationships that exist between library schools and their host libraries in the academic political process has not been explored.

Internship and field work experience are the subjects from the broad spectrum of possible cooperative ventures that have generated the most interest among practitioners, educators, and researchers. Their history and reasons for renewed interest in them in the 1980s, including the rise of post-M.L.S. programs and research residencies, have been described. Additionally, researchers have dealt with the mutually beneficial aspects of faculty and professional development, the need for streamlined educational programs for the information age, and the alleged lack of communication between professors and the profession.

Only Jack Dalton addressed directly the state of relations between the schools and their host academic libraries by sending a qualitative open-ended letter of inquiry to a limited sample of deans and directors in the early 1970 s. He gathered information pertaining to shared space and resources, staff relations, librarians as teachers, and teachers as librarians. His, however, was not a systematic attempt to survey both parties within a given institution or to correlate responses by commonality of affiliation. In view of the many new developments, it is time to ascertain existing patterns and practices and to propose new ideas and structures that may promote interaction and communication between the two units so that each can increase its utility to the parent institution.

Supported by a Council On Library Resources Cooperative Faculty/Librarian Grant, the authors undertook a project to ascertain the relationships and institutional needs that exist in the 1980 s between library schools and their host libraries in the academic political process in the New York metropolitan area. This article reports on the following aspects of the study:

1. The range of methods and techniques that libraries and library schools in the New York metropolitan area have jointly developed to promote a dialogue and interaction and to fill identified needs

2. Factors that appear to increase cooperation between the two units

3. Factors that appear to create conflict and to hinder joint efforts between the two units

4. The impact that various forms of interaction or lack thereof have on the education of future library/information professionals

We selected five institutions for indepth study: Columbia University, Long Island University, Pratt Institute, Queens College of the City University of New York, and St. John's University. These form a particularly interesting sample because they vary considerably in age, size, history and tradition, administrative structure, and number of campuses. They also represent the private and public sectors, and secular and parochial institutions of higher learning. These attributes and the compact geographic locale offered a unique opportunity to conduct the investigation.

Data collection, lasting approximately six months from mid-November 1986 through late April 1987, became a multifaceted effort, since the aim of the study was to ascertain the current state of affairs between two separate but obviously related organizational units within an academic entity. Detailed information about New York institutions was gathered by conducting twenty-three interviews with a broad sample of academic personnel, including deans and directors as well as those to whom they report, such as executive vice-presidents, academic vicepresidents, and associate provosts. Additional viewpoints were obtained from library school librarians and/or library science bibliographers. Input from these individuals was invaluable for gaining a realistic and comprehensive picture of the local situation.

In order to obtain, as background, the broad national picture, we mailed identical questionnaires to the deans of fifty-five accredited library schools in the United States and Canada and to the directors of their host libraries. The identical survey 
instrument was used to determine the extent to which our respondents' assessments of various issues and factors agreed. The response rate was unusually high: 86 percent from directors and 91 percent from deans. Data thus collected were entered into a standard spreadsheet computer program [LOTUS 1-2-3] and analyzed for this study. Concern and interest in the subject matter and the homogeneity of the sample were, undoubtedly, contributing factors to the high return rate of the questionnaires.

\section{LIBRARIANS AND LIBRARY EDUCATION \\ Librarians as Teachers}

Over the years librarians have aligned themselves with the teaching profession on all levels of the enterprise. While fighting for faculty status, for example, librarians frequently argued that the only difference between classroom and library instruction is the location. Since emphasis on providing bibliographic instruction and end user training in the various aspects of information and data manipulation and searching has increased, examining the various teaching roles librarians play in academe was a natural and necessary step for this project.

Most deans, directors, and administrators at the five institutions in the regional sample consider teaching by librarians to be a contribution to the profession and to the library school. Nevertheless, they caution that while it broadens librarians' horizons and enriches their careers, it can also have a negative effect on inadequately funded and understaffed libraries. Some administrators also indicate that while they favor librarians teaching specialized courses, such as law librarianship, they do not approve of them teaching other courses, whether basic or advanced. They reason that many librarians do not hold $\mathrm{Ph}$.D. degrees and thus often lack training in research methodology. Their teaching tends to be application oriented with neither an adequate theoretical balance nor the perspective gained from ongoing research and publishing.

Because of their central location in a large metropolitan area, rich in cultural and academic institutions and human resources, the five institutions have an extensive pool of potential adjunct instructors available to supplement their faculty. Still, on the average, one to three librarians from the host libraries teach in their institutions' library school each year, usually offering courses in specialized topics such as government documents or legal resources. Others are periodically asked to give guest lectures. Although most directors indicate that, schedules permitting, they would like to teach, in reality none was found to do so. Three metropolitan area directors are listed in their schools' bulletins by name and title; two are also noted as adjunct professors.

Compensation for librarians who teach as adjuncts is often impractical because of institutional regulations that prohibit payment to an individual twice by the same agency. This was indicated in both the interviews and the questionnaire responses. Possible solutions include granting adjuncts release time from their regular jobs, which in turn is paid for by the library school as a contribution to the library, or having librarians teach after normal working hours and providing them with compensatory time. In both cases, however, the parameters of the regular positions remain unaltered, leading in reality to substantially increased work loads without additional monetary rewards. Clearly, compensation can become a barrier to cooperation between practitioners and educators in certain organizational contexts. This is the most likely reason why schools prefer to keep their options open while deciding whether they should hire adjuncts from the outside or utilize available institutional human resources in filling adjunct lines. Naturally, where payment restrictions do not exist, librarians can have dual appointments and be paid for teaching according to their rank or position within the prevailing institutional classification system.

The national sample indicates that librarians teach regularly scheduled courses in library schools in 65 percent of the institutions. Orientation lectures are similarly common, occurring in 60 percent of the cases. Guest lectureship is an activ- 
ity of which everyone approves; over 90 percent of the respondents indicate that librarians participate. In contrast to the frequent occurrence of the above solo instructional activities, team teaching is relatively uncommon. An opportunity for valuable cooperation is, apparently, being missed.

Whether library science students receive bibliographic instruction as part of their curricula and the extent to which it is a cooperative effort between librarians and library school faculties are important factors in assessing the relationship between the two units. Our findings indicate that nowhere in the New York sample is bibliographic instruction formally part of the curriculum; it also appears to be a low priority for library schools nationally. Uniformly, schools neither offer bibliographic instruction to their students themselves nor do they take advantage of the instructional services available from their institutions' libraries. Faculty with expertise in the field might help design a course for the library's use but they will not participate in its execution. This is, in part, because compensation for teaching undergraduate courses is not as high as for graduate courses.

All libraries in our metropolitan sample offer bibliographic instruction to undergraduate and to some graduate students at their institutions. Except for one institution where every freshman is expected to pass a basic library skills course, none require it, and it usually bears no credit. Thus, it is ironic that many undergraduate and some graduate and professional students at the five institutions routinely participate in bibliographic instruction sometime during their education while most library science students, who are themselves likely to provide bibliographic instruction during their professional career, will not have benefited from such offering at all. It seems that these students are shortchanged just because their field of specialization is library/information science.

Another potential vehicle for cooperation between libraries and library schools is internship. For the purposes of this study, it is defined as a credit-bearing pro-
“. . . all interviewees consider internship programs important for training future professionals and would like to expand them in their institutions."

gram that combines classroom instruction and practicum for which students generally do not receive financial compensation. Three institutions ( 60 percent) in the metropolitan area and 70 percent of the schools nationwide offer such programs. The remaining two New York schools (40 percent) offer students programs they refer to as internships whereby students receive a stipend for supervised work/study experience in the library. Regardless of the differences, all interviewees consider internship programs important for training future professionals and would like to expand them in their institutions. Participation in internship programs is, uniformly, not a required component of the curriculum except in the school library/media center specialization, where it is mandatory for certification in most states.

Deans and directors agree that internships must be academically justified and must provide interns with appropriate professional-level experience; the temptation to use interns to fill short-term pressing staff needs should be avoided. All advocate a strict interviewing, selection and review process, and recognize the right of the library administration to make the final decision to accept or reject each nominee.

Opinions are strongly divided about how successful internship programs are as joint cooperative undertakings between the two units (see figure 1). Deans, directors and administrators regionally rate internship programs in their institutions from moderately successful to unsuccessful. Nationally, about 50 percent of the respondents indicate moderate or great success while about 40 percent consider their program unsuccessful. The remaining 10 percent offered no opinions.

The perceived lack of success of intern- 


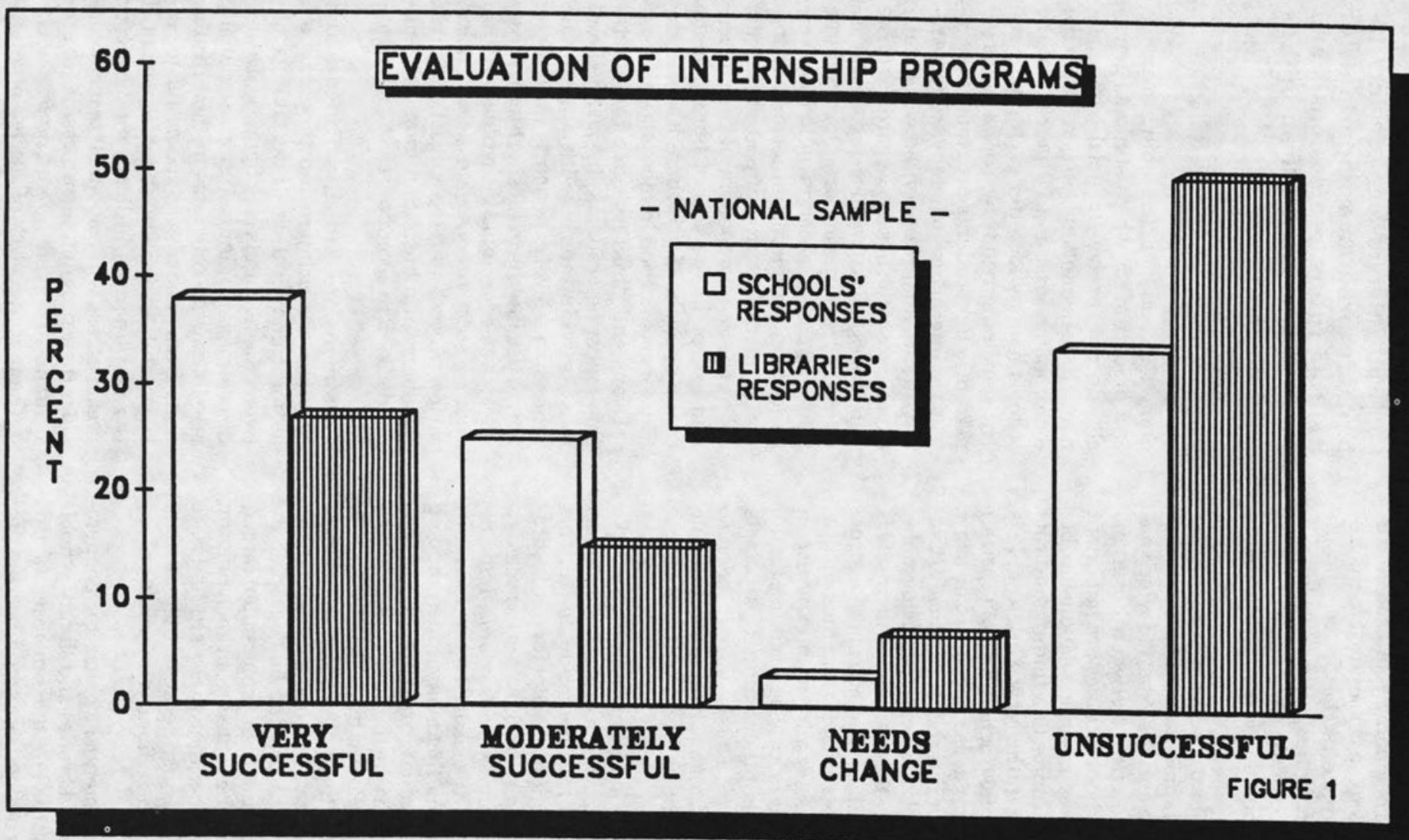


ships is attributable to several factors. Many students prefer internships outside the academic environment, believing that jobs are more plentiful in nonacademic libraries. As a result, the available local pool of applicants is often considerably diminished. Others do not consider the experience to be professionally meaningful. The reason most commonly offered, however, arises from the primary mission of the libraries. Their purpose is to serve broad institutional needs, and meeting educational needs of library school interns places an additional, often intolerable, burden on financial resources and schedules of the already short supply of qualified supervisors. Thus, the inability to commit adequate supervisory time and effort often becomes a major barrier to the success of internship programs.

Career counseling and mentoring of future professionals is another activity in which librarians and library school faculty might productively cooperate. Assisting future librarians in preparing for their careers is particularly important at a time when the information world is changing rapidly and requirements for information specialists in academic libraries in the next decade will be drastically different from today's. Directors and administrators emphasize the need for librarians to provide guidance in the students' socialization process, considering this an opportunity to make a contribution to their profession.

In view of the strong agreement on the importance of career counseling and mentoring, it is surprising that no formal programs for this activity exist either regionally or nationally. Naturally, librarians individually in all institutions offer advice to students informally, when requested. Initiative for establishing the mentorstudent relationship often originates with the library school librarian who is most aware of the students' needs. Strengthening and formalizing career counseling programs will help librarians and library school faculty to fulfill their professional obligation to their future colleagues.

\section{Librarians as Students: Continuing Education}

At a time when the M.L.S. degree is in- creasingly considered a permit to enter the profession rather than the end of all educational requirements for practice in the profession, continuing education has become the major vehicle for ongoing professional development. Paraprofessional and clerical employees also need extra training so that they too can keep up with new developments. This is fertile ground for cooperation between practitioners and educators on campus.

All New York institutions offer doctoral and/or advanced certificate programs that attract students from their libraries' professional staff. Some also offer minicourses and workshops that are open to all employees. The number of librarians participating in the various programs ranges from 0 to 3 per institution annually. Nationally, library directors indicate that continuing professional education is thriving at over 70 percent of the institutions and that, on the average, 2.7 professional librarians and 6.7 support staff per institution are enrolled per year.

All metropolitan-area institutions offer tuition exemption to their full-time professional and nonprofessional staff. The figures nationally show that somewhat more than half of the institutions offer this benefit to professionals and somewhat less than half offer it to support staff. Clearly, the availability of this tuition-free education is an incentive for self-improvement. Schools have a golden opportunity to extend their services to their parent institution by becoming a major provider of continuing education and training opportunities.

\section{LIBRARY SCHOOL FACULTY} AND THE LIBRAKY

\section{The Library as a \\ Laboratory for Instruction}

Library schools have traditionally utilized their host library and its resources for instructional purposes. Whether the nature and extent of this long-standing practice of cooperation are changing as a result of external developments, such as the advent of technologies in the management and operation of libraries, is an important aspect of this study.

Like most academic libraries, those in 
our local sample use electronic technologies for many of their operations. The same technologies have also become an integral component of library school curricula. Therefore, sharing of hardware by the two units would seem logical and costeffective from an institutional perspective. Yet all the schools in our metropolitan sample and the majority of schools nationally have their own computer laboratories and independent access to major bibliographic utilities and database vendors for the use of their students. Deans, directors, and administrators agree that such duplication is inevitable and even necessary because of the two units' differing missions and goals. They believe that educational and operational requirements should not be mixed for reasons of economy. The chances for success and mutual satisfaction in a shared environment are minimal. Duplication of equipment does not usually occur, however, where turnkey systems are used. The need for hands-on experience is minimal, and is usually satisfied by faculty bringing their classes to the library for demonstrations once or twice a semester.

Thus, technology neither fosters nor hinders cooperation between librarians and library school faculty. In fact, both groups agree that sharing equipment is neither beneficial nor advantageous to them or to students.

As anticipated, the library's primary laboratory use still centers on the teaching of reference and subject bibliography. There is a high degree of concurrence among respondents in the high usage ratings they give these two teaching specialties. (See figure 2.) The longstanding partnership between the two units in this area is as strong as ever.

\section{Collection Development}

Primary responsibility for library/information science collection development both in New York and nationally rests either with a full-time library school librarian or with a bibliographer who also selects for other disciplines. Three of the schools studied in New York (60 percent) have full-time library science librarians, two of whom have subject Ph.D.s The re- maining two schools have part-time selectors. Of those responding, nationally, 44 percent of the selectors are full-time and 25 percent part-time.

Library school faculty are involved in the selection process in all five New York institutions and in over 50 percent of the sample nationally. The degree to which they have input into the selection process depends on whether the library has a fulltime library science librarian, the library's collection policy, and the size of its budget. Most New York library schools are small, averaging eight full-time faculty members, and, in contrast to other academic departments, do not appoint a faculty liaison to the library. Even in the school that has a faculty liaison, his/her role is coordination rather than primary selection. In institutions where the library science librarian also selects in other disciplines, directors welcome greater involvement in the selection process on the part of the school's faculty.

The availability of funds in academic libraries to support teaching and research programs often becomes a point of contention between faculty and practitioners. It was, therefore, important to ascertain the relative size of library/information science materials budgets vis-à-vis total institutional library budgets. Nearly all directors locally and nationally indicated that the allocation constitutes 5 percent or less of the total library materials budget. However, a sizeable number of the deans nationally ( 22 percent) reported that their budgets exceed 15 percent of the library's total allocation even though directors of their host libraries put the figure at 5 percent. General naiveté and noninterest in overall library budgeting could account for the misconception.

\section{Faculty Development}

We described above several programs that enable librarians to continue their professional development. There are programs available to faculty to obtain similar results. These include participation in activities sponsored by various organizations, working in reference or managerial positions in host libraries, and serving as consultants to other library agencies. 


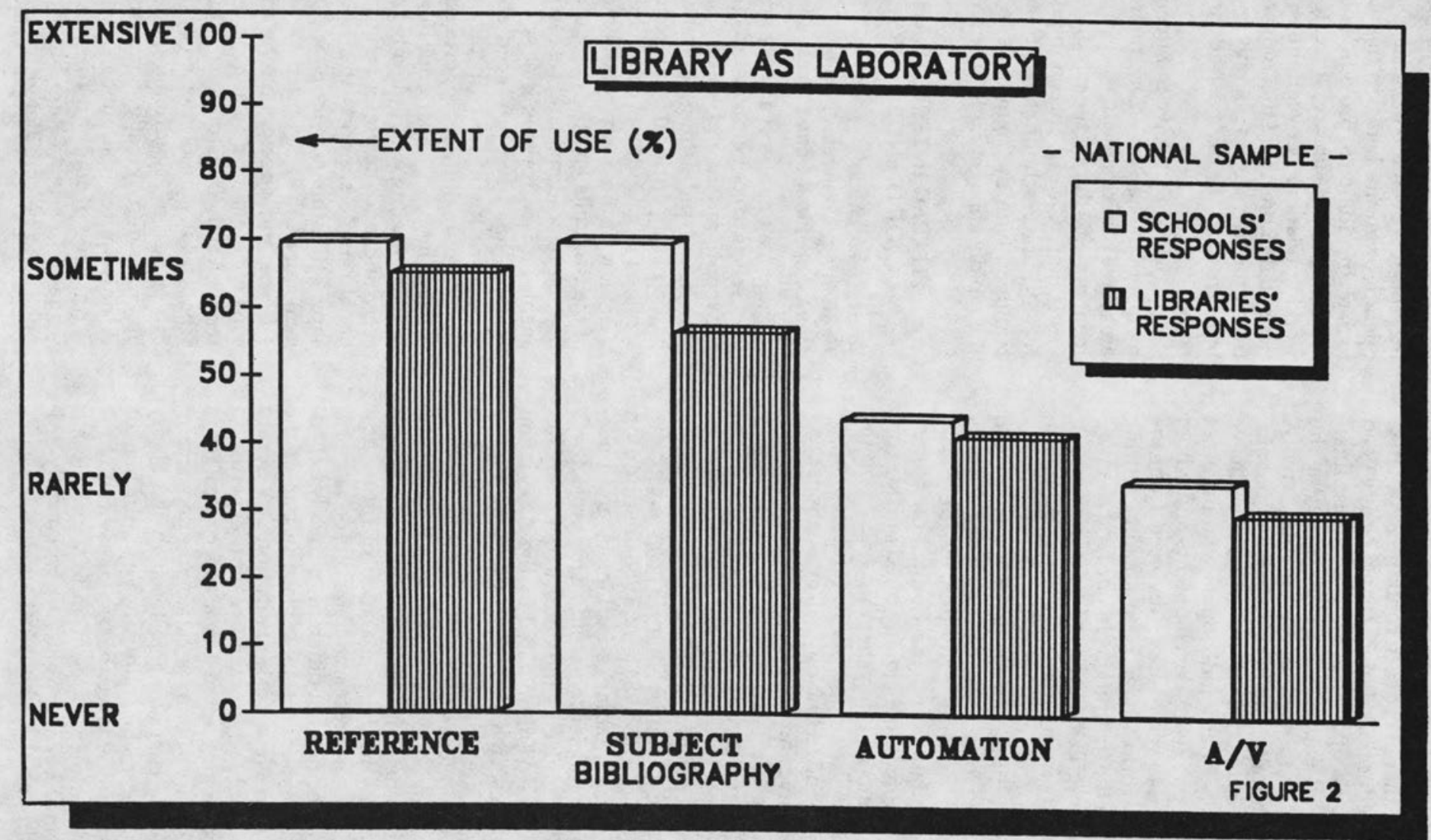

돌. 
Deans, directors, and administrators believe that in order to continue to be effective educators, library school faculty need periodic updating. None of those interviewed expressed a preference for the type or form of developmental activity. Specifically, the host library was not singled out as the most effective or exclusive agency. Many individuals who have not kept pace with developments and whom directors refer to as "divorced from the real world" have been steadily retiring from the institutions in our local sample.

Recognizing the need to remain current, faculty from three of the library schools in New York undertook a notable cooperative venture during $1981 / 82$, one that did not involve their host libraries directly. With funding provided by the Exxon Foundation and the Council on Library Resources, they jointly hired outside consultants to bring them up to date on the latest developments in information science and technology. All evaluations were positive and the experience was deemed a success.

Three faculty members at one of the schools benefited from another development program that, once again, did not involve their host library. They were graduates of the 1984 and 1986 Institute on Research Libraries for Library and Information Science Faculty. This project was also funded by the Council on Library Resources, but operated by the Association of Research Libraries. Although the immediate goal of this undertaking is to build closer working relationships between educators and research librarians, the long-term aim is to assist library school faculty in the preparation of future academic and research librarians.

A somewhat different, mutually beneficial experience took place in one of the other New York institutions. A library school faculty member with expertise in cataloging spent a year as a consultant in the host library's cataloging department while continuing to teach in the library school. The following year, during his sabbatical leave, he served as head of the department, a position to which he has since been appointed permanently. Although the school lost a valuable faculty member, both dean and director agree that this has been the most successful cooperative venture between the two units to date. In addition to providing new leadership within the library, it created closer working relations between the two faculties and demonstrated that movement between the two sectors not only is possible but can work to the best advantage of both.

Approximately twelve to fifteen faculty members in the New York metropolitan area have participated in various development projects during the period of this investigation. Clearly, it is an important effort if library school students are to be equipped with the right tools to work in the rapidly changing information arena.

\section{SHARED INTERESTS AND JOINT ENDEAVORS}

\section{Joint Research and \\ Publishing, Conferences and Workshops, and Committees}

Three major areas of activity might lend themselves to cooperation and interaction between librarians and educators: joint research and publishing, organizing and participating in local conferences, and serving on institutional committees.

In view of the many common concerns of the two units and the numerous issues relating to academic and research librarianship, it is surprising that so little joint research has been produced at the five New York institutions in recent years. Only two institutions report cooperative projects by practitioner/educator teamsresearch dealing with indexing and online searching, and the present study. The national sample supports this finding and shows that this activity is a low-priority item among the respondents.

Deans and directors offer various reasons for the almost total absence of joint research at their institutions. While library school faculty are all affected by the "publish or perish" syndrome, guidelines for librarians differ greatly. Some institutions do not require publications, others require it only for promotion to senior ranks, while at one institution librarians must publish to be considered for tenure and 
promotion to any rank. There seems to be no clearly stated incentive and advantage to pursuing joint research at this time, although administrators at some of the institutions are beginning to encourage members of both units to concentrate their research efforts on issues that will advance institutional goals and objectives. Topics mentioned include information and archival management and electronic publishing.

Arranging local conferences and workshops provides another potential vehicle for cooperation between the two units. The number of such jointly sponsored events in both the metropolitan and national samples has been small in recent years. Some were initiated by the schools, while others resulted from grass roots efforts by either unit, without planning by deans or directors. Librarians participated primarily by attending and sometimes by organizing sessions or presenting papers, while educators tended to be program coordinators or presenters of research. Less formal endeavors such as career days for students and alumni of the school and convocations for new students also provided a forum for members of the two units to exchange ideas and form relationships.

Educators and practitioners in New York and nationwide regularly serve together on institutional committees. There is interaction between the two units through various ad hoc committees as well. Wherever a library committee appointed by the institution's governing body exists, it usually includes a member of the library school faculty who provides input in policy matters and often acts as liaison between the library and the governing body. Library science librarians, especially in institutions with separate library school collections, through their membership on the schools' curriculum and/or instructional committees, provide a strong link between the two units. Clearly, New York findings are representative of the national picture regarding potential for cooperation in the above three areas. Educators and librarians in the same institution interact only to a very limited degree; they apparently have other priorities.

\section{Employment of \\ Library School Graduates}

As part of the investigation of relationships between library schools and their host libraries we sought to determine whether libraries in our sample hire graduates of their library schools, and whether the chances of these graduates for employment were better, equal, or worse than those of candidates who graduated from other library schools.

All five New York institutions employ graduates of their local library school. In fact, they constitute between 10 to 50 percent of the library staff, with larger numbers in the older institutions. Directors and academic administrators uniformly believe that giving preference to one's own graduates results in inbreeding and is thus a disservice to the students, the institution and the profession. They all claim not to give preferential treatment and to strive for diversity and excellence in their staffs. As new administrators and staff are increasingly being recruited nationally, there is growing diversification of background and education among younger librarians and those hired more recently.

Unlike directors and administrators, New York deans are far less similar in their opinions concerning their institutions' libraries hiring their schools' graduates. While they recognize directors' needs for national recruitment to achieve healthy staff diversification, they nevertheless express satisfaction that many of the libraries' professionals are former students of their respective schools. They also claim that library schools are dynamic, continuously changing organizational units due to faculty turnover, new deans, and a continuously revised curriculum. Therefore, they believe that libraries can and should continue to hire graduates of their institutions' schools without fear of inbreeding and parochialism.

Data from the broad sample support the New York findings. Eighty percent of the libraries hire graduates of their institutions' library schools "regularly" and "occasionally," as illustrated in figure 3. In 65 percent of these libraries local graduates make up a substantial portion of the library staff. 


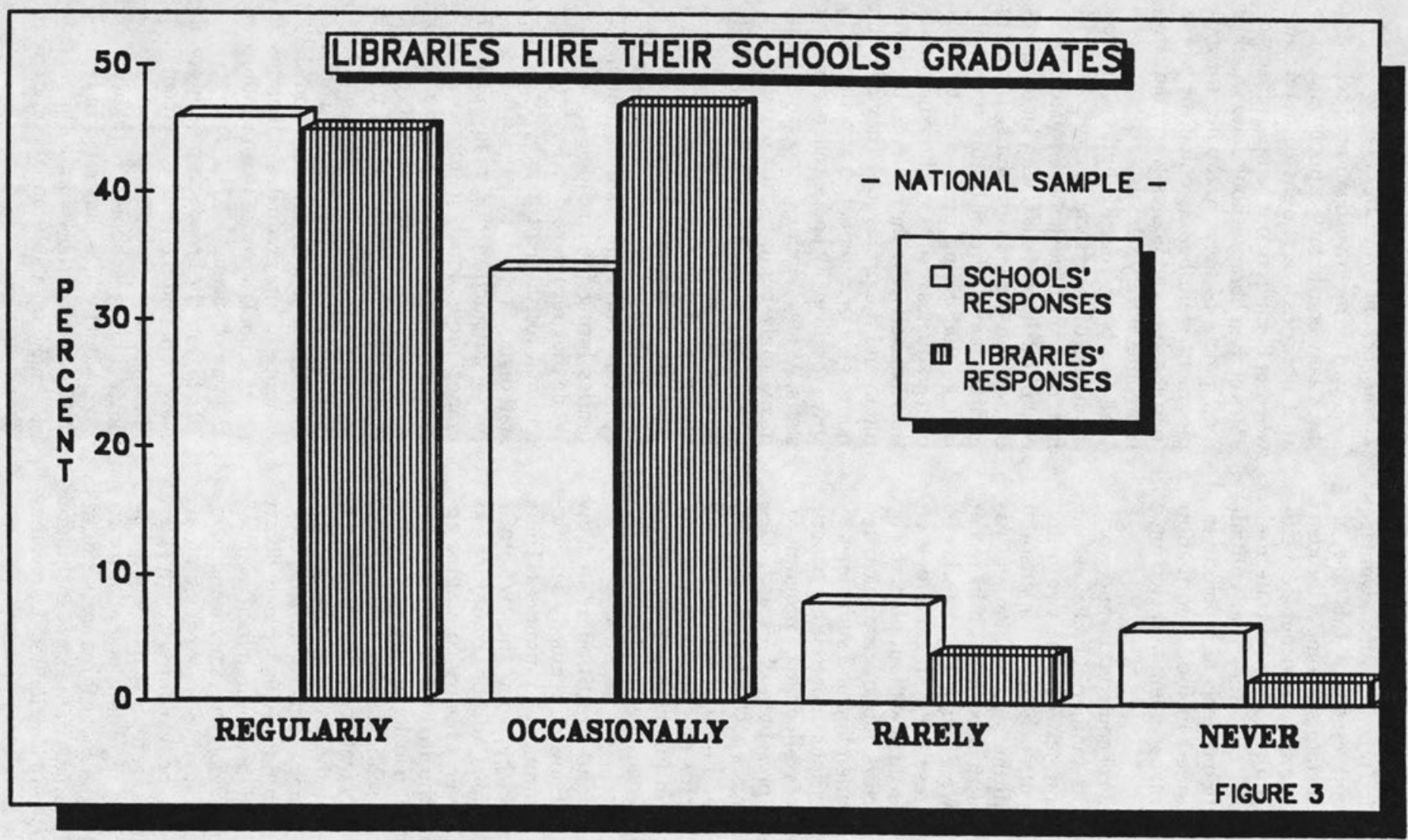


As already noted, all New York institutions offer free tuition to their clerical employees. This institutional policy in part accounts for the fact that all libraries employ several professionals who attended library school while working as clerks or paraprofessionals in the library. As the shortage of qualified professionals becomes more apparent and tuition continues to rise, this interaction between the two units is likely to continue and expand. However, as greater emphasis is placed on diversity and more librarians are recruited nationally, future graduates will increasingly compete with outside candidates and will no longer receive preferential treatment because of their work experience in the library.

\section{Personnel Matters}

Library schools and their host libraries are administratively separate units in all five New York institutions. Schools, as academic departments with an educational mission, and libraries, whose mission is service to the institutions' community, report to different administrators, and their units are part of different divisions, academic or otherwise, of their universities. The two units have separate committees dealing with personnel and budget matters and there is no formal interaction between them. Opinions of deans and directors, and sometimes faculty and staff, are, however, often solicited informally on prospective hires, particularly those with specialized expertise, as well as during tenure and promotion deliberations.

Deans and directors are frequently asked to serve on search committees for their counterparts. This occurred at three of the institutions studied but did not guarantee eventual close relations between the two individuals in any case. The finalist at one institution, for example, had been nominated for the position by his counterpart but later the initially close relationship was replaced by indifference and minimal interaction between the individuals and their units. Findings are similar in the other cases also, indicating that the initial spirit of cooperation may wane primarily for political reasons.
The national data fully support the New York findings. A pattern of minimal interaction exists between the two units in recruitment, tenure, promotion, and other personnel matters. Clearly, maintaining their integrity and independence is a high priority for both the library and the school and it is sanctioned by the academic hierarchy.

\section{"A pattern of minimal interaction ex- ists between the two units in recruit- ment, tenure, promotion, and other personnel matters."}

\section{Building Projects}

In an era of shrinking budgets for academic institutions, new building programs are rare, and even major renovations of existing structures are uncommon occurrences. Our New York sample is, therefore, rather unique since it includes private institutions that have in recent years renovated library and library school buildings, and a public institution that has built a new, state-of-the-art library that is shared with the school. New library buildings, especially those that are jointly occupied, and renovations of existing buildings offer unusual opportunities for interaction between librarians and educators both in the planning process and after completion of construction. Unfortunately, however, the interaction was found to be limited both locally and nationally. Such projects do offer other advantages, however, including increased campus visibility and awareness of either or both units.

\section{CHANNELS OF COMMUNICATION}

Communication, the channels through which it is conducted, and their perceived effectiveness and importance contribute to the relationships that emerge between units in any organization. Findings both locally and nationally indicate that libraries and library schools communicate 
with each other through various channels, both formal and informal, in the performance of their responsibilities. Deans and directors expressed overwhelming preference for informal channels and agreed that these are the most effective means for accomplishing tasks. Nationally, they rated mutual distribution of newsletters and publications the most frequently used and most effective formal channel of communication. Regardless of the means, however, both groups of administrators stressed the need for maintaining open communication between themselves and their units. Responses from forty-seven libraries and fifty schools in the national sample are presented in figures 4 and 5 . It is noteworthy that, for most cases, schools consistently rate both frequency of usage and effectiveness higher for all types of communication than libraries do.

The library school librarian/library science bibliographer is considered by both parties and the librarians themselves to be the primary and most effective formal link in the communication process between the two units. Three institutions in New York have full-time library school librarians. At the other two, a reference librarian is responsible for the selection and maintenance of library science materials, as well as for materials in other disciplines.

Deans, directors, and administrators all stress the role of library school librarians both as representatives of the director and as links with the schools. Librarians attend all faculty meetings and are ex officio members of the schools' curriculum and/ or instructional committees. All involved agree that this type of communication creates closer and more open relations between the library and the library school, but caution that communication does not necessarily ensure good relations between the top administrators of the two units.

In the two institutions which do not have full-time library school librarians, interactions are less formalized and less frequent. Deans and directors claim to meet informally when issues of common concern arise, but there is neither regular representation at department meetings nor exchange of minutes. Information flows primarily between the top administrators and filters down as they deem appropriate.

Deans and directors at institutions without full-time library school librarians are pragmatic about the effect the absence of this position has on their relations. They realize that it is politically important for the library school to have a separate library science collection with a full-time librarian managing it. At the same time, they are cognizant of the fact that in many academic institutions financial constraints rule out the ideal and force them to live with acceptable compromises. The whole academic library, in their view, is a laboratory, and they encourage their students to use it as such. They do not necessarily feel that the lack of a separate library science collection and a library science librarian is a deprivation for their students.

\section{CONCLUSION}

Relations between library schools and their host academic libraries are complex and unique. While a common professional bond exists between them, each has different missions and goals that limit their possible cooperation. The old conflict between theoreticians and practitioners remains an obstacle to working together. Institutional and state regulations as well as general budgetary constraints may create additional barriers and further impede progress toward shared programs and joint ventures between the two units. Nevertheless, all academic administrators, deans, and directors who provided information for this study believe that interaction and cooperation between the two units are desirable and feasible.

Power in the academic environment has, in recent years, become synonymous with ownership of the latest technology. Both units are heavily dependent on computers and each has its own equipment. In the context of this study, such duplication was found to be a barrier to joint efforts at times. Information technologies, however, can also become an incentive for collaboration. They offer the two units numerous opportunities to work together while simultaneously furthering their goals and objectives.

The following are specific recommenda- 


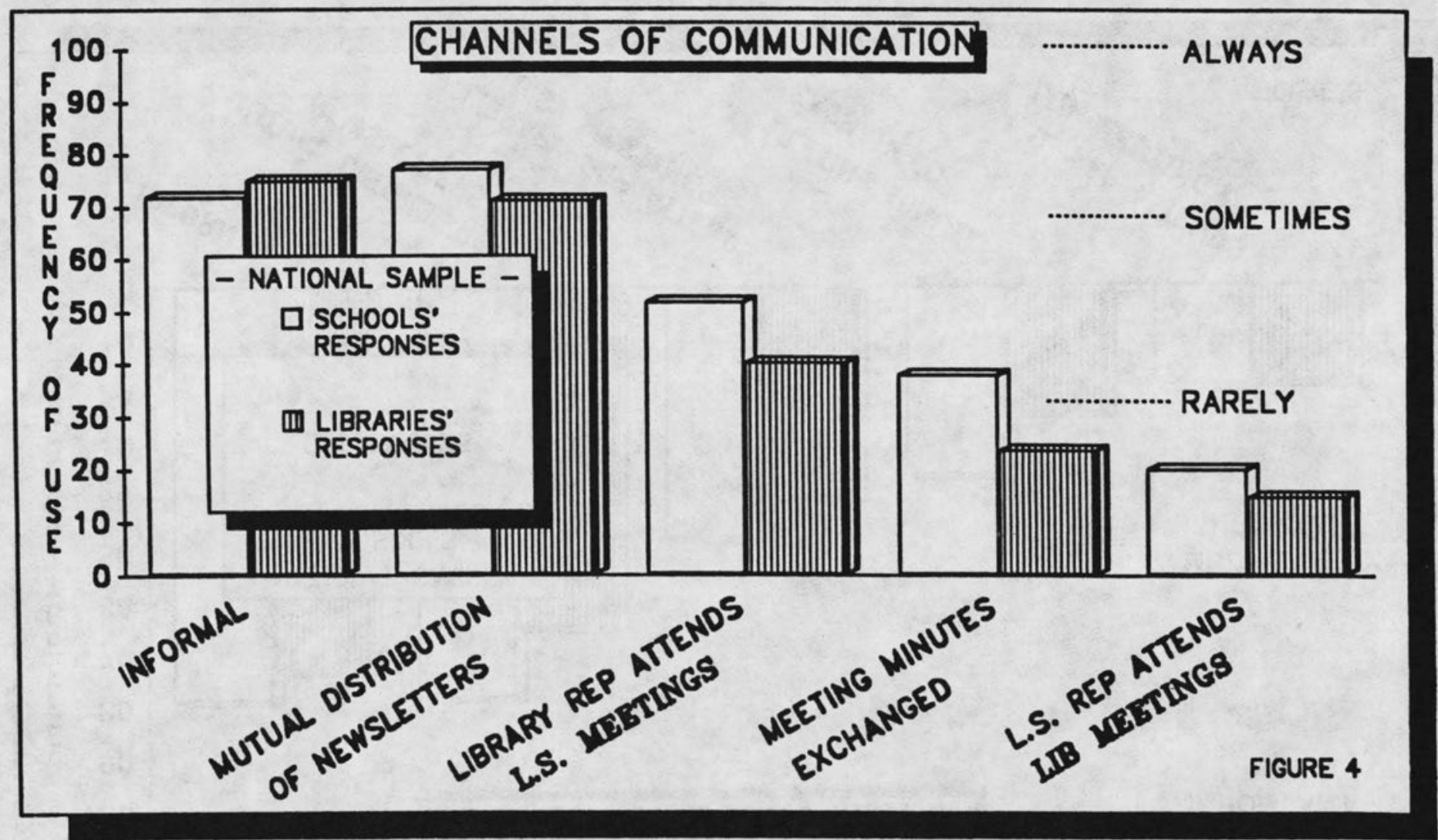




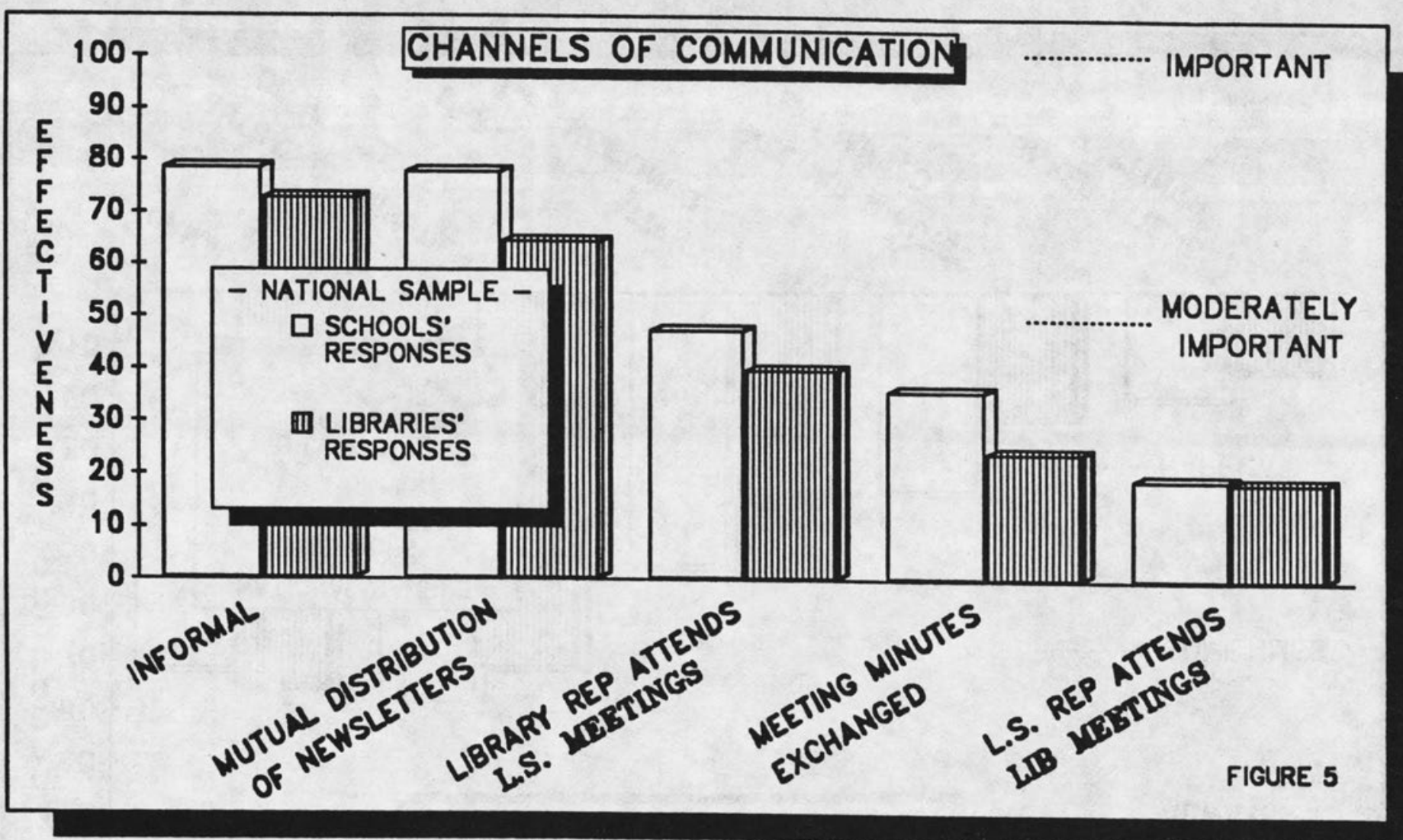


tions that the authors believe would promote cooperation, communication, and interaction between library schools and their host libraries while also improving the education of future library/information professionals.

The concept of the host academic library as a laboratory for the library school needs to be substantially expanded. Rather than serving merely as the setting for the teaching of reference and subject bibliography, the library should assume a role similar to that of teaching hospitals, where future professionals learn first-hand the practice of their chosen craft. Current library school graduates have limited knowledge and experience with the realities that management frequently faces, including budget cuts, problem employees, and vandalism, as well as new building programs and the design and implementation of innovative services. These and other issues are ideal subjects for a new component of the curriculum.

Librarians can and should contribute more appreciably to the education of library/information science students on their campuses. Institutional barriers to proper financial compensation for librarians who teach in their library school should be eliminated. Internships, considered by all deans and directors to be important for career development, should become a requirement for all library/information science students who have no experience in the field, not just for those specializing in the school library/media center area. Deans and directors must make administrators aware of the importance of internship to the educational process so that the major barrier, the shortage of qualified supervisors in the library, can be overcome. Libraries must be adequately supported by their parent institutions to allow their professional staff to devote time and attention to the proper supervision of student interns.

Librarians with distinct specialties should be formally enlisted by the schools to serve as mentors/advisors to those wishing to pursue similar paths. Providing career guidance to their students is a major responsibility of educational institutions. Therefore, taking advantage of lo- cal experts should ease their burden while simultaneously fostering closer relations between the two units.

Bibliographic instruction should become a formal and integral component of the library/information science curriculum. Students need to be exposed to both theory and practice, since most of them will be expected to provide this service to their clientele, regardless of the type of library in which they will be employed. Enlisting the host library staff to provide instruction would be a logical avenue of cooperation between the two units.

Diversity in libraries' employment practices should continue. However, as long as even one local graduate is hired, schools need a mechanism to monitor his/her career regularly. These graduates could contribute appreciably to the educational process by serving as role models and mentors to those enrolled in the program. Simultaneously, they would represent a significant link between the library and the school.

In view of the ever-increasing need for continuing education and professional development of both practitioners and educators, schools and their host libraries should become barrier-free centers for members of both units for such activities. While tuition-exemption policies enable librarians in most institutions to further their education in their schools, academic administrators need to provide the means and incentives to encourage educators to participate in professional development and to accept their host libraries as viable settings for such efforts.

To survive and flourish library schools and their host libraries must forge a political alliance while maintaining their autonomy. Together they would have a stronger voice on campus and be better able to exert influence and generate funding for various joint ventures to support and further the goals and mission of their parent institution. In order to explore avenues of how these recommendations might best be implemented as well as how other issues dealing with relationships between the two units might best be addressed, a broadly based examination of the topic should be undertaken by the As- 
sociation of Library and Information Science Education or the American Library Association, with the Council on Library
Resources or other national funding agencies providing financial support.

\section{BIBLIOGRAPHY}

Battin, Patricia. "Developing University and Research Library Professionals: A Director's Perspective." American Libraries 14:22-25 (January 1983).

Coburn, Louis. Classroom and Field: The Internship in American Library Education. Flushing, N.Y.: Queens College, 1980.

Conant, Ralph W. The Conant Report: A Study of the Education of Librarians. Cambridge, Mass.: MIT Press, 1980.

Dain, Phyllis. "The Profession and the Professors." Library Journal 105:1701-07 (September 1, 1980).

Dalton, Jack. "The Library and the Library School: Some Ruminations on Relationships." The Academic Library. Essays in Honor of Guy R. Lyle. Ed. by Evan I. Farber and Ruth Walling. Metuchen, N.J.: Scarecrow, 1974, p.24-38.

Dougherty, Richard M., and W. P. Lougee. "Research Library Residency; A New Model for Professional Development." Library Journal 108:1322-24 (July 1983).

Dyer, Esther, and Daniel O'Connor. "Crisis in Library Education." Wilson Library Bulletin 57(10):860-63 (1983).

Hill, Fred E., and Robert Hauptmann. "A New Perspective on Faculty Status." College and Research Libraries 47:156-59 (March 1986).

Holley, E. G. "Extended Library Education Programs in the U.S." Advances in Librarianship 11:51-76 (1981).

Martin, Susan K. "Library Education: An Administrator's View." Library Journal 111:115-17 (February 15, 1986).

Research Libraries and Library Schools. Proceedings of a Meeting of the Canadian Association of Research Libraries and the Canadian Council of Library Schools. Saskatoon, Saskatchewan, Canada, June 9, 1982.

Stueart, Robert D. Cooperation Between Library Schools and the Profession. Paper presented at the Greater Boston Public Library Administrators Meeting. Boston, Mass: September 18, 1975.

White, Herbert S. "The Library Education Accreditation Process: A Retreat From Insistence on Excellence." Library Journal 105:2377-82 (1980).

White, Herbert S. "Library Education Programs: Independence and Mergers." Library Journal 112:84-85 (June 1, 1987).

Witucke, Virginia. "Library School Policies Toward Preprofessional Work Experience." Journal of Education for Librarianship 16(3):162-72 (1976).

By the 1930's, the great push toward comprehensive bibliographical control of periodical and monographic literature, with which the century had commenced, was definitely over, and attention was directed to the basis rather than to the actuality of control. 